\title{
A Nodule-Specific Gene Family from Alnus glutinosa Encodes Glycine- and Histidine-Rich Proteins Expressed in the Early Stages of Actinorhizal Nodule Development
}

\author{
Katharina Pawlowski, ${ }^{1}$ Paul Twigg, ${ }^{2,3}$ Svetlana Dobritsa, ${ }^{3,4}$ Changhui Guan, ${ }^{1}$ and Beth C. Mullin ${ }^{3}$ \\ ${ }^{1}$ Department of Molecular Biology, Agricultural University, 6703 HA Wageningen, The Netherlands; \\ ${ }^{2}$ Department of Biology, University of Nebraska at Kearney, Kearney 68849, U.S.A.; ${ }^{3}$ Department of \\ Botany and Center for Legume Research, University of Tennessee, Knoxville 37996, U.S.A.; ${ }^{4}$ Institute of \\ Biochemistry and Physiology of Microorganisms, Russian Academy of Sciences, Pushchino, Moscow \\ Region, 142292, Russia \\ Received 11 October 1996. Accepted 20 March 1997.
}

Two cDNAs representing different members (agNt84 and ag164) of a gene family encoding glycine- and histidinerich proteins have been isolated from cDNA libraries from Alnus glutinosa root nodules. Expression of the corresponding genes could only be detected in nodules. With in situ hybridization, the expression in nodules was found to occur in young, infected cells of the prefixation zone (zone 2). The encoded proteins contain putative signal peptides for targeting to the endomembrane system, sharing sequence similarity with signal peptides from plant glycinerich proteins, among them nodulin 24 , a nodule-specific protein from soybean. This similarity suggests that, analogous to nodulin-24, proteins encoded by agNt84/ag164 may be located at the interface between the host plant membrane and the matrix surrounding the endosymbiont. The $3^{\prime}$ untranslated regions of the cDNAs contain unusual $\operatorname{poly}(\mathrm{AT})_{\mathrm{n}}$ stretches that may play a role in the regulation of RNA stability. The protein encoded by agNt84 cDNA was expressed in Escherichia coli as a fusion with maltosebinding protein, and was shown to have the ability to bind to a nickel-chelating resin, indicating that it may function as a metal-binding protein.

Additional keywords: actinorhizal, nitrogen fixation.

Two groups of plants, legumes (Mylona et al. 1995) and actinorhizal plants (Benson and Silvester 1993), can interact with certain soil bacteria and form specialized organs, the root

Corresponding author: Katharina Pawlowski

E-mail: kpawlow@gwdg.de

Present address of Katharina Pawlowski: Institut für Biochemie der Pflanze, Untere Karspüle 2, 37073 Göttingen, Germany.

Present address of Changhui Guan: Institut für Biochemie der Pflanze, Untere Karspüle 2, 37073 Göttingen, Germany.

Nucleotide and/or amino acid sequence data are to be found at GenBank as accession numbers U69156, V00452, M29259, L02212, U38031, R90270, T38798, X60387, U09989, X14058, X14059, and X15122, and at EMBL as accession number Y08436. nodules, where the bacteria fix nitrogen while being hosted in plant cells. While legume nodules have a stemlike morphology with peripheral vascular system and infected cells in the central tissue (Mylona et al. 1995), actinorhizal nodules consist of multiple lobes, each representing a modified lateral root without a root cap, with a superficial periderm and infected cells in the expanded cortex (Benson and Silvester 1993). The shared features of these two symbioses have been discussed in a recent review (Pawlowski and Bisseling 1996). The development of both types of root nodules involves the coordinated expression of several genes encoding functions specific for the symbiosis. Nodule-specific gene expression has been analyzed extensively in Rhizobium-induced legume nodules (for reviews, see Sánchez et al. 1991; Mylona et al. 1995) and recently has also been studied in actinorhizal nodules induced by Frankia (Goetting-Minesky and Mullin 1994; Ribeiro et al. 1995). One general aim of studying nodule-specific gene expression is the analysis of the function of the gene products. However, except for genes whose products are involved in nodule metabolism, the function of the products of most nodule-specific genes is still unknown. For instance, some putative cell wall proteins, e.g., ENOD5 and ENOD12, have been suggested to be involved in the infection process, but their precise role is not known (Scheres et al. 1990a, 1990b). We have been particularly interested in understanding the role of proteins that function at the interface between the symbiont and the host plant because the events that occur here are likely to be critical for successful symbioses.

In nitrogen-fixing root nodules, the composition of the interface between the symbionts, i.e., the peribacteroid space in legume nodules and the cell wall-derived encapsulation material surrounding Frankia in actinorhizal nodules, must be a crucial factor in enabling and controlling the symbiotic interaction. In spite of the dissimilarity of microsymbionts and nodule structure, actinorhizal and Rhizobium-legume symbioses have several points in common (Mylona et al. 1995; Pawlowski and Bisseling 1996). Thus, the question arises whether there is some similarity between the protein components of the matrix surrounding the endosymbiont in both symbioses. 
Several legume nodule-specific cDNAs encoding proteins targeted to the peribacteroid space have been identified (for review, see Sánchez et al. 1991). In actinorhizal symbioses, however, only two proteases and a putative structural protein have been identified as possible components of the matrix surrounding intracellular Frankia (Goetting-Minesky and Mullin 1994; Ribeiro et al. 1995; Guan et al. 1997).

In order to identify actinorhizal nodule-specific genes encoding proteins that might be involved at the interface between the host and the endosymbiont, cDNA libraries made from Alnus glutinosa nodule RNA were screened differentially with nodule and root cDNA. Two nodule-specific cDNAs encoding putative membrane-targeted proteins were selected for further study as described below.

\section{RESULTS}

\section{Characterization of nodule-specific cDNA clones} pAgNt84 and pAg164.

The screening of the two A. glutinosa nodule cDNA libraries yielded several clones hybridizing strongly with nodule and not with root cDNA (Twigg 1993; Ribeiro et al. 1995). These cDNAs were further characterized by RNA gel blot hybridization against nodule and root cDNA, respectively, and by sequencing. Sequence analysis showed that the inserts of two clones from the different libraries, pAgNt84 (GenBank accession number U69156) and pAg164 (EMBL accession number Y08436), displayed high DNA sequence similarity, encoded homologous proteins, and thus represented members of the same gene family (Fig. 1A, B). DNA gel blot hybridization with inserts from pAg164 and pAgNt84 suggests that they represent members of a larger gene family (Fig. 2).

The comparison of the two cDNA sequences reveals that in spite of high overall sequence similarity, there is one 27-bp insertion in the coding region of agNt84 cDNA and two insertions of $44 \mathrm{bp}$ each in the $3^{\prime}$ untranslated region (UTR) of ag164 cDNA (Fig. 1A). The sequences of the insertions indicate that they may be the result of sequence duplications. The insertion in the coding region of agNt84 cDNA more or less consists of two motifs present either $5^{\prime}$ or $3^{\prime}$ to the insertion site. The insertions present in the $3^{\prime}$ UTR of ag 164 cDNA are long $(\mathrm{AT})_{\mathrm{n}}$ stretches that are adjacent to the sites of shorter

\section{B}

AgNt84 1 MGYSKTFLLLGLAFAVVLLISSDVSASELAVAAQTKENMQTDGVEEDKYH 50 Ag164 1 MGYFNTFLLLGLVFAVVLLISSDVSAGELVGATQTKENMQTDGAEEVKYH 50

AgNt84 51 GHRHVHGHGHGEVHGNGNEHGHGHHHGRGHPGHGAAADETETETETNQN 99 Ag164 51 GHRHVHGHGHGNGHG . . . . . . HHGHGHSGHVVAADETETDRN 86

\section{C}

AgNt 841 MGYSKTELLLGLAFAVVLLISSDVSASEL 29

Ag164 1 MGYFNTFLLLGLVFAVVLLISSDVSAGEL 29

DCGRP 1 MGSKI. FLLLGLSIAFALLISSEVAAREL 28

CrGRP 1 MGSKI. FLLLGLSIAFAILISSEVAAREL 28

$\begin{array}{lll}\text { CrGRP } & 1 \text { MGSKI. FLLLGLSIAFAILISSEVAAREL } \\ \text { NTGRP } & 1 \text { MGSK. AFLFLGLCLAFFFLISSEVVAGEL } 28\end{array}$

LECWP 1 MGSK. AILFLGLFLAIFLMISSEVAAREL 28

GmNOD24 1 MGSKMAILILGL. LAMLLLITSEVAARNL 28
172 GTGCGGAGGAGGTCAAGTATCATGGCCATCGTCACGTGCATGGACATGGG 221

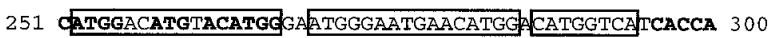

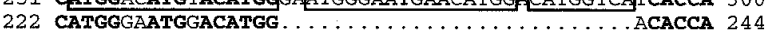

301 CGGCCGTGGTCACCCAGGACACGGTGCTGCTGCAGACGAGACAGAAAC. 348 245 CGGCCATGGTCACTCGGGACATGTTGTTGCTGCTGATGAGACAGAAATG 294

349 . CGAAACTGAAACCAACCAAAATPAGACCAATCTTTTGATTCGTCCTAT 396 295 ATCGAAATTAAACCAATCAAAATTAGACGAATCCTTCGATTCGTCCTAT 344

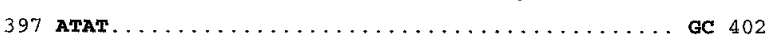
345 ATATATATATATATATATATATATATATATACACATATTGACATATATGC 394 403 TATCAGTTGTACGTACGTCTAAGTGTGTCTAAGTCGMAATATGTGGCTTA 452 395 TATCAG.... CTATACATCTGAGTGTGTCTAAGTCGTCTTATGTGGCTTA 440

453 ATTATCTAATTAAGCTTGTATGCCAATAAACTTTATGTTTCTACTTTTGT 502 441 ATTATCTAATTAAGCTTGTATGCCAATAAACTTTATGTTTCTACTTTTGT 490

503 CATGTGTAATTTTTGCTTTTCMATGTATTACAATGTACGCTGPAGCATAT 552 491 CATGTGTAATTTCTGCTTTTTTATGTATTAAAATGTACGCTGTAGCATAT 540

557 CAAAATTAAACGAATCCTMTGTCCTATATATATATATAT ...... 576 545 CAAAATTAAACGAATCCTTTGTCCTATATATATATATATATATATATATA 590

$577 \ldots \ldots \ldots \ldots \ldots \ldots \ldots \ldots \ldots$ GCAACTTPTGAAAGGCT 608 591 TATATATATATATATATATATATATATATATATGCAACTTTTGAAAGTT 640

612 GTACGTGAATAAGATTATATTGGATGAATATATAGTTTATGAATTCTAAA 658 641 GTACGTGAATAAGATTATATTGGCTGAATAAATAGTTTATGAATTCT 687

Fig. 1. Sequence comparisons. A, DNA sequence comparison of agNt84 and ag164 cDNAs. Upper sequence is agNt84 cDNA; bottom sequence is ag164 cDNA. Gaps have been introduced to optimize the alignment. Identical nucleotides in conserved positions are in bold. Translational start and stop codons are underlined. Sequences making up insertion in the agNt84 cDNA coding region are boxed. Two direct repeats conserved in both sequences are indicated by arrows. B, Sequence comparison between AgNt84 and Ag164. Gaps have been introduced to optimize the alignments. Conserved amino acids in identical positions are in bold. Beginning of putative mature polypeptide according to von Heijne (1986) is marked by a star. C, Signal peptide comparison between AgNt84/Ag164 and glycine-rich proteins from other plants. DcGRP, carrot glycine-rich protein (Aleith and Richter 1990); CrGRP, Chenopodium rubrum glycine-rich protein (Kaldenhoff and Richter 1989); NtGRP, tobacco glycine-rich protein (Van Kan et al. 1988); LeCWP, tomato cell wall protein (Domingo et al. 1994); GmNOD24, soybean nodulin-24 (Katinakis and Verma 1985). Gaps have been introduced to optimize the alignments. Amino acids conserved in at least four sequences are in bold. 
$(\mathrm{AT})_{\mathrm{n}}$ stretches conserved in both sequences. These $(\mathrm{AT})_{\mathrm{n}}$ insertions may be responsible for the weakly hybridizing bands in the complex DNA gel blot hybridization pattern (Fig. 2).

agNt84 cDNA encodes a $10.57-\mathrm{kDa}$ protein of 99 amino acids (aa; AgNt84, also called AgNOD-GHRP), with a pI of 6.45. ag164 cDNA encodes a $9.19-\mathrm{kDa}$ protein of 86 aa (Ag164), with a pI of 6.51. Both AgNt84 and Ag164 contain putative N-terminal signal peptides (Fig. 1B), as defined by von Heijne (1986). Both proteins have an $\mathrm{N}$-terminal glycine residue that is a potential target for myristylation (Persing et al. 1987) and both have several potential phosphorylation sites as defined by Kemp and Pearson (1990). AgNt84 has three

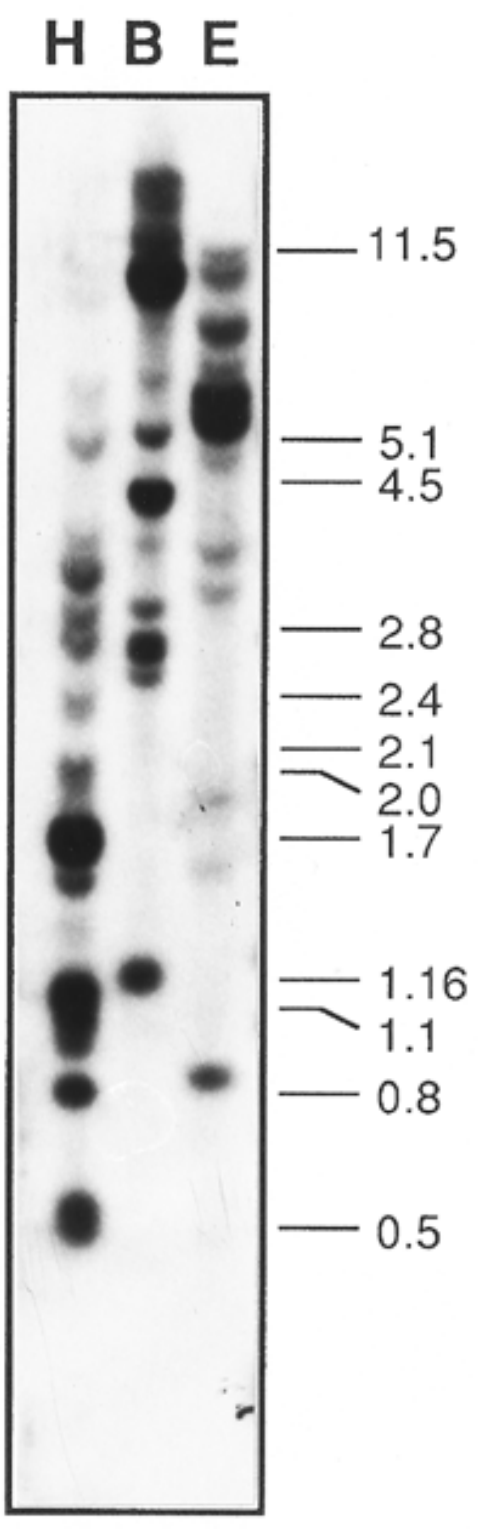

Fig. 2. DNA gel blot analysis. Total DNA from A. glutinosa was digested with EcoRI, BamHI, and HindIII, respectively, separated on an agarose gel, and blotted onto Amersham Hybond $\mathrm{N}^{+}$membrane. Sizes of marker fragments are given in kb. Hybridization pattern of agNt84 was similar, with some differences in relative intensity of bands (data not shown). Both ag164 and agNt84 cDNAs are cut by EcoRI and HindIII, but not by BamHI. casein kinase (CK)II-like recognition sites (S/TXXE/D) S*ASE and T*ET*ETE-and three CKI-like recognition sites (E/DXXS/T)_ETET*ET*ET*. Ag164 has two CKII-like sites-S*AGE and T*ETD—and one CKI-like site-ETET*. Data base searches revealed that the putative N-terminal signal peptides displayed high sequence similarity to signal peptides of some glycine-rich proteins from other plants (Fig. 1C), one of them being a nodule-specific protein from soybean, nodulin-24 (Katinakis and Verma 1985). For the putative mature polypeptide sequences, no homologs were found in the data bases.

\section{Gene expression of $a g N t 84$ and $a g 164$.}

The expression patterns of agNt84 and agl64 were analyzed by RNA gel blot hybridization. Blots containing equal amounts of total RNA from roots, nodules, shoot tips, male and female flowers, and developing fruits of A. glutinosa were hybridized with the inserts of pAgNt84 and pAg164, respectively. For both genes, expression could be detected only in nodules. The results are shown in Figure 3.

To localize expression in nodules, in situ hybridization of longitudinal sections of $A$. glutinosa and A. incana nodule lobes was performed with sense and antisense RNA of $a g N t 84$ and ag164 cDNA, respectively. In situ hybridizations with antisense RNA of the Frankia nitrogenase structural gene nifH as a probe were performed on adjacent sections (Fig. 4A, B) to obtain a marker for the developmental gradient of the cortical cells (Ribeiro et al. 1995). The developmental gradient as defined by Ribeiro et al. (1995) for actinorhizal nodules consists of four zones. Zone 1 at the distal end of the nodule consists of the meristematic tissue; zone 2 consists of nonmeristematic cells, some of which become infected with Frankia filaments that subsequently form vesicles; zone 3 is the zone of nitrogen fixation as defined by nif gene expression; and zone 4 , at the proximal end of the nodule, is the zone of senescence. The in situ hybridization results show that agNt84/ ag164 are expressed in the infected cortical cells of zone 2 (Fig. 4C, D, and E). These cells, while being gradually filled with Frankia hyphae from the center outward, do not yet express Frankia nifH. Thus, agNt84/ag164 are expressed during the infection of nodule cortical cells by Frankia, before the onset of bacterial nitrogen fixation. In contrast to ag12, the first nodule-specific gene from A. glutinosa found to be expressed at high levels in infected cells of zone 2 (Ribeiro et al. 1995), agNt84/ag164 do not show detectable levels of expression in infected cells of zone 3 . No hybridization signal was seen in any tissue with the sense RNA probe (data not shown).

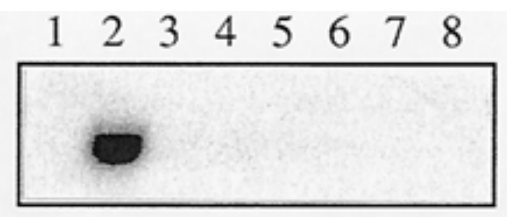

Fig. 3. RNA gel blot analysis. Approximately $10 \mu \mathrm{g}$ of total RNA from $A$. glutinosa roots (1), nodules (2), shoot tips (3), male flowers (4), female flowers (5), and developing fruits harvested in April (6), June (7), and September (8), was separated on an agarose gel and blotted onto Genescreen membrane. Blot was hybridized with the insert of pAg164. Hybridization with the insert of pAgNt84 yielded identical results (data not shown). Equal loading and transfer were confirmed by hybridization with a soybean ubiquitin probe (Kouchi and Hata, 1993; data not shown). 


\section{In vitro expression of AgNt84 in Escherichia coli.}

In the course of cloning the protein-coding sequence from pAgNt84 into the pMAL-c2 expression vector to produce fusions with the maltose-binding protein (MBP), it became evident that expression of the entire sequence of $\mathrm{AgNt} 84$ in $E$. coli is lethal to the bacterium. Transformation efficiencies were very low and most transformants examined produced recombinant proteins with deletions in the AgNt84 leader sequence or had frame-shift mutations that caused the protein of interest not to be produced. In those rare cases when recombinant plasmids did contain the entire AgNt84 coding sequence (clones 1-1 and 1-13), a second, vector-size plasmid was present in the cells, which resulted in expression of both the fusion protein $(53.3 \mathrm{kDa})$ and a MBP-size protein $(42.7 \mathrm{kDa})$ by the cultures upon IPTG induction (Fig. 5). Protein expression in those clones eventually led to cell death between 2 and $3 \mathrm{~h}$ of induction (Dobritsa and Mullin 1996). A deletion clone (III-41) in which the first 16 aa of the AgNt84 signal peptide are missing expressed a nontoxic fusion protein. High levels of expression of this truncated fusion protein $(51.6 \mathrm{kDa})$ were demonstrated in induced cells of this clone, and at least 100 $\mathrm{mg}$ of the fusion protein could be purified from the cell soluble fraction on an amylose resin column per liter of culture.

The pMAL-c2 expression vector has a Factor Xa protease site between MBP and the target protein. Cleavage of the purified fusion protein from clone III-41 with Factor Xa to obtain truncated AgNt84 with no MBP-derived amino acids showed that the fusion protein was completely cleaved within $1 \mathrm{~h}$, with two protein bands visible on a Coomassie brilliant bluestained sodium dodecyl sulfate-polyacrylamide gel electrophoresis (SDS-PAGE) gel. One band corresponded to a major part of MBP, the other band was about $15.1 \mathrm{kDa}$. Only upon prolonged incubation could a band of the expected size (about $8.9 \mathrm{kDa}$ ) be observed in SDS-PAGE gels (Fig. 6). It is evident, from the gradual disappearance of the $15.1-\mathrm{kDa}$ band and the parallel increase in intensity of the $8.9-\mathrm{kDa}$ band in the course of cleavage, that the latter is released as a secondary product of cleavage of the $15.1-\mathrm{kDa}$ peptide. In turn, the 8.9-kDa peptide could be partially converted, at higher Factor Xa concentrations and/or times of incubation, into a peptide of about $6.9 \mathrm{kDa}$ (data not shown). Factor $\mathrm{Xa}$ cleavage in the presence of low SDS concentrations resulted in even less spe-
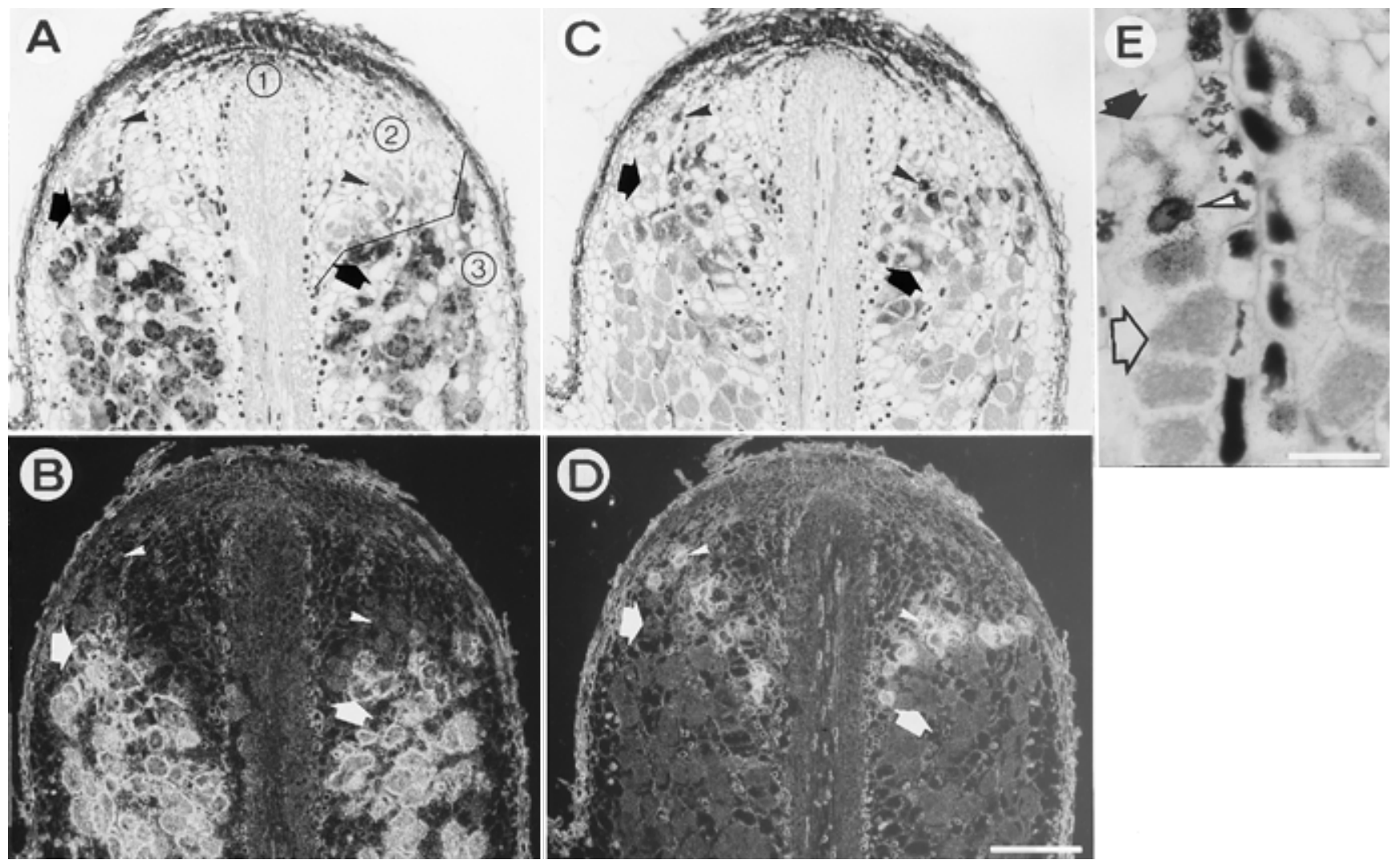

Fig. 4. In situ localization of agNt84/ag164 mRNA. In A, C, and E, bright field microscopy was used; silver grains denoting hybridization appear as black dots. In $\mathbf{B}$ and $\mathbf{D}$, dark-field microscopy was used; silver grains are visible as white dots. Slides were exposed for 4 weeks. A, B, Expression of Frankia nifH in a longitudinal section of an A. incana nodule lobe. Arrowheads point to infected cells of zone 2 that are not yet completely filled with hyphae and do not contain vesicles. In these cells, Frankia nifH is not expressed. Arrows point to infected cells of zone 3 that contain Frankia vesicles where nifH is expressed. Zones 1 (meristem), 2 (infection zone), and 3 (fixation zone) are indicated. A thin black line marks the border between zones 2 and 3. C, D, Expression of ag164 in an adjacent section of the same nodule lobe. Arrowheads point to infected cells of zone 2 that are not yet completely filled with hyphae and thus do not contain vesicles or express Frankia nifH. In these cells, ag164 is expressed at a high level. Arrows point at infected cells of zone 3 that contain vesicles and express Frankia nifH. In these cells, ag164 expression cannot be detected. Bar $=500 \mu \mathrm{m}$. E, Expression of ag164 in the course of development of infected cells of an A. glutinosa nodule. A black arrow is pointing at a file of infected cells of graded age. Upon infection, silver grains denote ag164 expression. ag164 expression reaches a maximum (arrowhead), is reduced again and is not detectable by the time vesicles are visible in the infected cell (open arrow). $B a r=125 \mu \mathrm{m}$. 
cific cleavage of the fusion protein (data not shown). The poor selectivity of Factor Xa cleavage resulted in a low yield of truncated $\mathrm{AgNt} 84$ under all conditions tested.

Direct sequencing of the $8.9-\mathrm{kDa}$ band excised from a Western blot (immunoblot) membrane gave the sequence VLLISSDV for the first 8 aa residues of the peptide, which confirms its identity with the truncated $\mathrm{AgNt} 84$ protein.

\section{Test of metal-binding ability of AgNt84.}

When a Factor $\mathrm{Xa}$ digest of purified, truncated MBPAgNt84 fusion was applied to a nickel column, most MBP flowed through the column during loading, with the rest being subsequently washed out with loading buffer. At the same time, the $8.9-\mathrm{kDa}$ Factor Xa cleavage product and truncated $\mathrm{AgNt} 84$, as well as its precursor, the $15.1-\mathrm{kDa}$ protein,

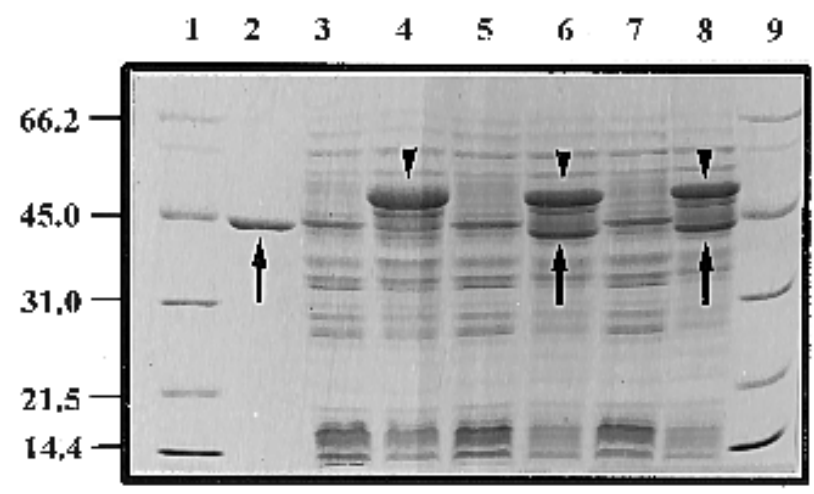

Fig. 5. Sodium dodecyl sulfate-polyacrylamide gel electrophoresis of protein samples from non-induced and isopropylthio- $\beta$-D-galactoside (IPTG)-induced cells of clone III-41 expressing the truncated AgNt84 fusion with maltose-binding protein (MBP), and clones 1-1 and 1-13 expressing full-length AgNt84 fusions with MBP. Lanes 1 and 9, protein molecular mass markers (sizes given in $\mathrm{kDa}$ ). Lane 2, MBP2* (New England Biolabs); lane 3, clone III-41, uninduced; lane 4, clone III-41, IPTG-induced; lane 5, clone 1-1, uninduced; lane 6, clone 1-1, IPTGinduced; lane 7, clone 1-13, uninduced; lane 8, clone 1-13, IPTGinduced. Black arrow heads point to the MBP-fusion proteins, and black arrows point to MBP

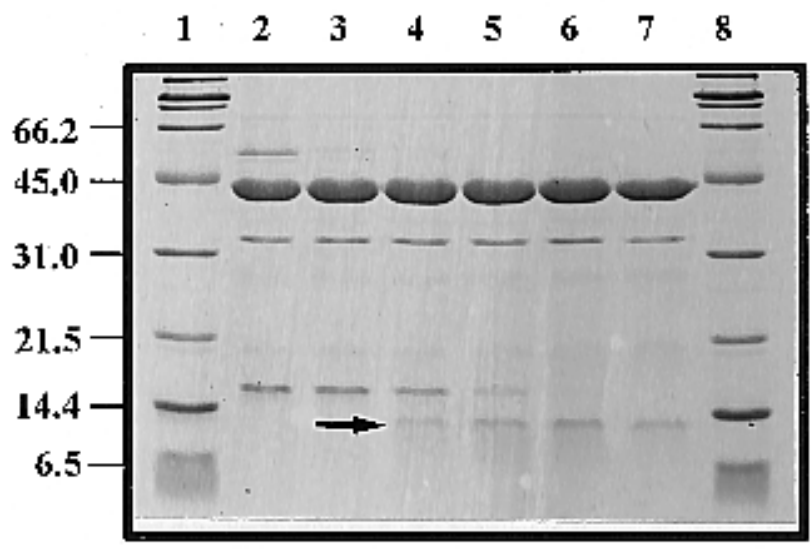

Fig. 6. Time course of cleavage with the protease Factor Xa of the fusion protein purified from clone III-41. Lanes 1 and 8, protein molecular mass markers (sizes given in $\mathrm{kDa}$ ). Lane 2, $30 \mathrm{~min}$; lane 3, $1 \mathrm{~h}$; lane 4, 2 $\mathrm{h}$; lane $5,4 \mathrm{~h}$; lane $6,8 \mathrm{~h}$; lane 7, $24 \mathrm{~h}$. Black arrow points to the 8.9$\mathrm{kDa}$ truncated $\mathrm{AgNt} 84$ protein. were found to specifically bind to the nickel-chelating resin and could be eluted with a buffer containing $300 \mathrm{mM}$ imidazole (Fig. 7). The specific binding to and subsequent release from the nickel-binding resin demonstrate the metal-binding potential of AgNt84.

\section{DISCUSSION}

A nodule-specific gene family expressed during infection.

We have shown that agNt84 and ag164 represent members of a small nodule-specific gene family in A. glutinosa, expressed at high levels in infected nodule cortical cells before the onset of bacterial nitrogen fixation. The polypeptides encoded by both cDNAs contain putative signal peptides for entering the endomembrane system (von Heijne 1986), but no signal for retention (Denecke et al. 1992). Thus, they may represent extracellular polypeptides. However, because signals for vacuolar targeting are diverse (Nakamura and Matsuoka 1993), it is not possible to rule out a vacuolar location for AgNt84/Ag164. The presence of an endomembrane targeting signal peptide combined with an expression pattern restricted to infected cells suggest that the polypeptides encoded by agNt84/ag164 may be located in the space between invaginated plasma membrane and Frankia, as has been suggested for another A. glutinosa nodule-specific protein, Ag12 (Ribeiro et al. 1995). However, the possibility exists that AgNt84 and Ag164 are myristylated and as a result may be anchored in a membrane rather than transported across a membrane. An N-terminal myristylation site and a series of Cterminal phosphorylation sites are reminiscent of the myristylated alanine-rich C-kinase substrate (MARCKS) of neurons, which reversibly associates with cell membranes depending upon its myristylation and phosphorylation status (McLaughlin and Aderem 1995).

Interestingly, the putative signal peptides of $\mathrm{AgNt} 84 / \mathrm{Ag} 164$ share high sequence similarity with the signal peptide of soybean nodulin-24, as well as those of several other plant glycinerich proteins (Fig. 1C). Immunolocalization studies have shown that nodulin-24 is located at the interface of the peribacteroid

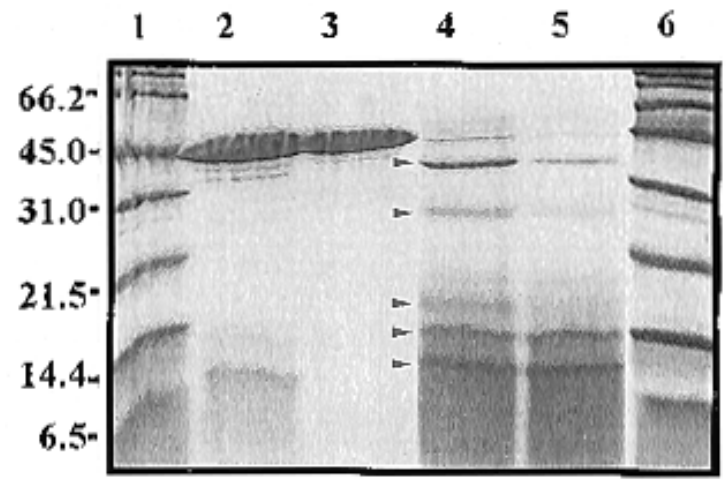

Fig. 7. Polyacrylamide gel electrophoresis of Factor Xa cleavage products of purified maltose-binding protein-truncated AgNt84 fusion chromatographed on a Probond nickel-chelating column. Lanes 1 and 6, protein molecular mass markers (sizes are given in $\mathrm{kDa}$ ). Lane 2, an aliquot of the sample prior to chromatography. Lane 3, protein eluted from the column by a wash with loading buffer. Lanes 4 and 5, protein eluted from column with buffer containing $300 \mathrm{mM}$ imidazole. Arrow heads point to Factor Xa cleavage products that are enriched by binding and release from the Probond column. 
membrane and peribacteroid space (Cheon et al. 1994). These data may indicate that conserved signal peptides are targeting all of these proteins to a particular extracellular compartment, i.e., to the interface between plasma membrane/ peribacteroid membrane and extracellular matrix/peribacteroid space. However, it has to be noted that there exists a glycine-rich protein targeted to the plasma membrane-cell wall interface that contains a nonhomologous signal peptide (Condit 1993).

\section{Unusual sequence of the conserved $3^{\prime}$ UTRs of agNt84 and ag164 cDNAs.}

There is extensive sequence identity in the long $3^{\prime}$ UTRs of agNt84 and ag164 cDNAs, suggesting an important role for these UTRs in regulation of the respective mRNAs. Both 3' UTRs are predicted to form extensive stem-loop structures. In addition, the 3' UTR of ag164 cDNA contains two (AT) stretches of 34 and $58 \mathrm{bp}$, respectively. AT repeats have been found in untranscribed genomic DNA regions of several organisms (Ermak et al. 1990; Johnson-Schlitz and Engels 1993), particularly in microsatellites (Morgante and Olivieri 1993), in introns of genes (GenBank accession numbers V00452, M29259, and L02212), and recently also in some partial plant cDNA sequences (GenBank accession numbers U38031, R90270, and T38798), as well as 3' of putative polyadenylation sites in gene sequences (GenBank accession numbers X60387, U09989, X14058, X14059, and X15122). These regions are known to be able to form stable secondary structures. In mammalian genomes, short direct repeats are considered to be unstable, since many of them are polymorphic in length (Farber et al. 1994). Both members of the agNt84/ag164 gene family seem to have evolved by internal duplications (Fig. 1A). It will be interesting to see in A. glutinosa plants from different stands whether the number of dinucleotide repeats in $a g 164$ is stable.

\section{In vitro expression of $\mathrm{AgNt84}$ in $\boldsymbol{E}$. coli.}

Cultures of clone III-41 expressing truncated AgNt84 were able to produce twice as much total protein as those of clones 11 and 1-13 expressing full-length AgNt84. Furthermore, these latter two cultures produced significant amounts of MBP and relatively small amounts of the AgNt84-MBP fusion protein. We have shown previously that full-length $\mathrm{AgNt} 84$ is toxic to $E$. coli cells (Dobritsa and Mullin 1996), a phenomenon that is consistent with its predicted $\mathrm{N}$-terminal membrane targeting signal.

Even though fusion proteins produced in E. coli can yield large quantities of material, separation of the target protein from the fusion partner by chemical or enzymatic means often presents a major problem. The Factor Xa site is generally considered to be the sequence IEGR, but some other sequences can also be recognized and cut by this protease (for a review, see Keil 1992). In our case, the primary cleavage site of the protease clearly lies within the MBP part of the fusion protein. Only after the MBP-AgNt84 fusion is cut at that noncanonical site, which results in production of the $15.1-\mathrm{kDa}$ hybrid peptide, does the IEGR site at the junction of the two partners of the fusion become accessible for Factor Xa cleavage to release truncated $\mathrm{AgNt} 84$. An additional cleavage site that is subsequently cut by the protease is most probably the GR site in the sequence HHGR within AgNt84, cleavage of which would release a peptide of about $6.9 \mathrm{kDa}$, containing the first 62 aa of truncated $\mathrm{AgNt} 84$.

\section{Possible function of AgNt84/Ag164 in symbiosis.}

The large number of histidine residues in the putative mature AgNt84 and Ag164 polypeptides suggests that they might be involved in the binding of metal ions, as is the case with histidine-rich stretches in other proteins (Wülfing et al. 1994; Fu et al. 1995; Gilbert et al. 1995). Alternating glycine and histidine residues, as in $\mathrm{AgNt} 84 / \mathrm{Ag} 164$ (Fig. 1B), are found in several proteins, for instance in a yeast protein involved in cobalt uptake (Conklin et al. 1992) and in mammalian highmolecular-weight kininogen shown to be involved in zincdependent binding to an anionic surface (de la Cadena and Colman 1992). Thus, AgNt84, whose metal-binding capacity was demonstrated by affinity chromatography on nickel columns, and Ag164, which possesses similar GH repeats, might represent metal-binding proteins.

Cysteine-containing metal-binding proteins with signal peptides for targeting to the endomembrane system occur in the compartment enclosing the bacterial symbiont in legume nodules. Some members of a nodule-specific soybean gene family, containing a cysteine-rich domain reminiscent of metal-binding domains (Sandal et al. 1987), are associated with the peribacteroid membrane (Jacobs et al. 1987). In pea nodules three such proteins, ENOD3, ENOD14, and NOD6, are expressed at different stages of the development of infected cells (Scheres et al. 1990a; Kardailsky et al. 1993).

During root nodule symbioses, the microsymbionts depend on the plant for carbon nutrition and trace elements. While molybdenum is a component of nitrogenase and therefore accumulates in nodules to a greater extent than in roots (Hewitt and Bond 1961), cobalt is the only mineral element known to be essential specifically for nodulated nitrogen-fixing plants, where it is needed for vitamin B12 synthesis in the microsymbiont (Hewitt and Bond 1966; Dixon and Wheeler 1983). Thus, a function in cobalt binding would be consistent with the strict nodule-specific expression pattern of agNt84/ag164. In any case, the transport of metal ions by the plant to the microsymbiont must be part of the symbiotic interaction. In this context, the existence of nodule-specific metal transport proteins would be expected. They could be part of the interface between both symbionts or contribute to metal storage in the vacuoles of infected plant cells.

In the future we plan to further characterize the metal-binding capacity and specificity of AgNt84/Ag164 as well as study the precise subcellular location of the proteins within nodule tissue. Such studies are necessary for the development of hypotheses related to the role of these proteins in symbiosis.

\section{MATERIALS AND METHODS}

\section{Plant material.}

Seed source and growth conditions as well as infection by Frankia have been described previously by Goetting-Minesky and Mullin (1994) for the cDNA library yielding pAgNt84, and by Ribeiro et al. (1995) for the cDNA library yielding pAg164. For isolation of root RNA, seedling roots were collected from uninfected plantlets 2 to 3 weeks after germination. For isolation of nodule RNA, nodules were harvested 8 to 12 weeks after infection. For isolation of shoot-tip RNA or genomic DNA, shoot tips including the two youngest, unfolded leaves were collected from plants 5 to 13 weeks after infection. Male and female flowers as well as developing 
fruits were collected from a local stand (Wageningen, The Netherlands). Flowers were collected in March 1994 and fruits in April, June, and September 1994.

\section{Isolation of nucleic acids.}

Total RNA was isolated either as described by Twigg (1993) or by Pawlowski et al. (1994). Total DNA was isolated by a modification of the method of Dellaporta et al. (1983).

\section{Cloning and sequencing procedures.}

DNA manipulations were carried out as described by Sambrook et al. (1989). Nucleotide sequences were determined by the dideoxy chain termination method (Sanger et al. 1977). Sequencing reactions were analyzed on acrylamide gels either manually or with an automated sequencer (model 373A; Applied Biosystems, Foster City, CA). Sequence data were analyzed with the programs of the Genetics Computer Group (Devereux et al. 1984). Data base searches were performed with the BLAST algorithm (Altschul et al. 1990) in the nucleotide sequence data bases of the National Center of Biotechnology Information, National Library of Medicine, and National Institutes of Health.

For the construction of the nodule-enriched cDNA library used for the isolation of pAgNt84, cDNA was synthesized from $4 \mu \mathrm{g}$ of poly(A) RNA from uninoculated roots or nodules with the Librarian II cDNA synthesis kit (Invitrogen, San Sorrento, CA) as directed by the manufacturer. Double-stranded cDNA was blunt-end ligated into the pcDNAII vector (Invitrogen). The cDNAs were then transformed into the host $E$. coli strain INV $1 \alpha \mathrm{F}^{\prime}$ (Invitrogen). A nodule-enriched cDNA library was generated for screening with the Subtractor kit (Invitrogen) as directed by the manufacturer. Aliquots of the root and nodule cDNA libraries were rescued as single-stranded molecules with R408 helper phage (Invitrogen). Twenty micrograms of the single-stranded root cDNA library was biotinylated with photobiotin (Invitrogen) and used in subtraction of $2.5 \mu \mathrm{g}$ of the single-stranded nodule cDNA library. The cDNAs were allowed to hybridize at $68^{\circ} \mathrm{C}$ for $48 \mathrm{~h}$, and were extracted twice with streptavidin (Invitrogen) and phenol/chloroform/isoamyl alcohol (25:24:1, vol/vol/vol). The resulting cDNA was treated with $E$. coli DNA polymerase I and T4 DNA ligase (Invitrogen) to obtain double-stranded cDNA clones. A nodule-enriched library was produced by transformation of these clones into $E$. coli INV $1 \alpha \mathrm{F}^{\prime}$.

The nodule-enriched library was initially screened with a subtracted cDNA probe produced with the Subtractor kit (Invitrogen) as directed by the manufacturer. One microgram of nodule RNA was used as template for the production of first-strand cDNA as above in the presence of $\left[\alpha-{ }^{32} \mathrm{P}\right] \mathrm{dCTP}$. This cDNA was subtracted with $5 \mu \mathrm{g}$ of photobiotinylated root mRNA made with the Subtractor kit (Invitrogen). Colonies were plated and transferred to Hybond $\mathrm{N}$ nylon membrane (Amersham, Arlington Heights, IL). After hybridization at $42^{\circ} \mathrm{C}$ in buffer containing $50 \%$ formamide, filters were washed at $65^{\circ} \mathrm{C}$ with decreasing salt concentrations down to $1 \times \operatorname{SSC}(0.15 \mathrm{M} \mathrm{NaCl}, 0.015 \mathrm{M}$ sodium citrate $), 0.1 \%$ SDS. Autoradiography was performed with X-Omat films (Kodak, Rochester, NY). A total of 200 clones were selected from this screening. Plasmid mini-preparations were performed for each of the clones, and samples of each plasmid were slot-blotted onto Hybond N nylon membrane with a Biodot SF 48-well blotting apparatus (BioRad Labs, Richmond, CA) as directed by the manufacturer. The slot blots were differentially screened with root and nodule first-strand cDNA produced as described above in the presence of $\left[\alpha{ }^{32} \mathrm{P}\right] \mathrm{dCTP}$. The hybridizations were performed as above, and filters were washed at $65^{\circ} \mathrm{C}$ with decreasing salt concentrations down to $0.1 \times \mathrm{SSC}$, $0.1 \%$ SDS. Following autoradiography, clones showing hybridization only to nodule cDNA were selected for further analysis. The construction and screening of the cDNA library used for the isolation of pAg164 has been described by Ribeiro et al. (1995).

\section{DNA and RNA gel blots and hybridization conditions.}

Northern (RNA) and Southern blots were prepared and hybridized as described by Ribeiro et al. (1995).

\section{In situ hybridization.}

Fixation and embedding of nodules has been described by Ribeiro et al. (1995). In situ hybridization with both sense and antisense RNA was performed as described by Cox and Goldberg (1988) and adapted by van de Wiel et al. (1990). Nodules of A. glutinosa and A. incana were used. The latter contain lower amounts of polyphenolic compounds and therefore are more suitable for in situ hybridization. A. glutinosa nodules were induced by Frankia strain WgAvcI1(DDB010130) and harvested 6 weeks after inoculation. A. incana nodules were induced by a local source of Frankia (spore-positive, uptake hydrogenase-negative) from Umeå University, Umeå, Sweden (Huss-Danell 1991) and harvested 6 to 8 weeks after inoculation.

\section{Construction of the vector expressing MBP-AgNt84 fusion protein.}

In order to obtain the $\mathrm{AgNt} 84$ protein for metal-binding studies, $\mathrm{AgNt} 84$ was expressed as a fusion protein in E. coli. Subcloning of the protein-coding sequence of pAgNt84 into the pMAL-c2 expression vector to obtain a fusion protein in which the protein of interest is linked to the $\mathrm{C}$-terminal region of MBP, and protein purification and analysis, were performed with the Protein Fusion \& Purification System (New England Biolabs, Beverly, MA), according to the manufacturer's directions. A 25-mer (5'-ATGGGTTACTCCAAGACT TTTCTTC-3') and a 20-mer (5'-GTTTATTGGCATACAAGC TT-3') derived from the agNt84 cDNA sequence (positions 74 to 98 and 464 to 483 , respectively) were used as amplification primers to obtain a 410 -bp polymerase chain reaction (PCR) fragment that codes for 99 aa of the $\mathrm{AgNt} 84$ protein and has a unique HindIII site at its $3^{\prime}$ end, downstream of the termination codon. The PCR fragment was gel purified, phosphorylated with T4 polynucleotide kinase, cut with HindIII, and ligated to the XmnI-HindIII-digested vector pMAL-c2, by standard protocols (Sambrook et al. 1989). Transformation of subcloning efficiency DH5 $\alpha$ competent cells (GibcoBRL, Gaithersburg, MD) was carried out according to the manufacturer's specifications. Transformants were selected on carbenicillin/X-gal (5-bromo-4-chloro-3-indolyl- $\beta$-D-galactoside) plates, and screening of plasmids for the insert was carried out by standard techniques (Sambrook et al. 1989). The correct reading frame of the fusion protein was checked by automated sequence analysis of recombinant plasmids in one direction with the malE primer (New England Biolabs), which anneals 
to the vector's malE gene, 78 bases upstream of the XmnI site, and additionally verified by sequencing the other strand with, as a primer, an oligonucleotide (5'-CATGATACTTATCCTC CTCC-3') that anneals to the cloned fragment, 131 bases downstream of its $5^{\prime}$ end. Truncated clone III-41 and fulllength clones 1-1 and 1-13 were selected as described by Dobritsa and Mullin (1996).

\section{In vitro expression and purification of AgNt84 fusion proteins.}

Expression of the fusion proteins was induced in clones III$41,1-1$, and $1-13$ by isopropylthio- $\beta-D-$ galactoside (IPTG, 0.3 $\mathrm{mM})$. The fusion protein from a crude cell extract of clone III41 , obtained by sonication, was purified on an amylose resin column (New England Biolabs). The purified fusion protein was incubated with protease Factor Xa (New England Biolabs, 1 to $2 \%$, wt/wt) under native conditions or in the presence of low SDS concentrations ( 0.005 to $0.05 \% \mathrm{wt} / \mathrm{vol})$, as directed by the manufacturer.

\section{Protein analysis.}

Solutions of the intact fusion protein were concentrated with Microcon- or Centricon-30 microconcentrators (Amicon, Beverly, MA). Factor Xa cleavage products were concentrated with Microcon- or Centricon-10 microconcentrators. Quantitation of proteins by the Bradford method with bovine serum albumin as a standard and one-dimensional SDS-PAGE of proteins were performed as described by Smith (1988a, 1988b).

\section{Protein sequencing.}

For protein microsequencing, SDS-PAGE gel-separated proteins were transferred onto a Westran PVDF membrane (Schleicher \& Schuell, Dassel, Germany) with a model 6000 horizontal semi-dry electroblotter (E \& K Scientific Products, Saratoga, CA). The band of interest was detected by staining with Coomassie brilliant blue R-250 as described (Matsudaira 1987) and excised for direct sequencing on a 477A Applied Biosystems instrument.

\section{Test of metal-binding activity.}

Factor Xa cleavage products of purified MBP-truncated AgNt84 fusion protein were chromatographed on a Probond nickel-chelating resin (Invitrogen) under native conditions according to the manufacturer's directions. Protein binding to the resin was monitored by PAGE.

\section{ACKNOWLEDGMENTS}

We would like to thank Tony van Kampen (Department of Molecular Biology, Wageningen Agricultural University) for DNA sequencing, Charles Murphy (University of Tennessee Medical Center at Knoxville) for protein sequencing, Jan van Heerd (Department of Microbiology, Wageningen Agricultural University) for growing A. glutinosa plants, Richard B. Hall (Iowa State University) for A. glutinosa seeds, and Olga Ruiz-Marin Kopp and William Scurry (Department of Botany, University of Tennessee) for inoculation, harvesting, and fixation of A. glutinosa nodules, and for data base searching respectively. We are indebted to Per-Olof Lundquist (University of Minnesota, St. Paul) for providing A. incana nodules. P. T. acknowledges the support of the Research Services Council of the University of Nebraska at Kearney. C. G. and K. P. were supported by the Nederlandse Organisatie voor Wetenschappelijk Onderzoek (NWO). The Chancellor of the University of Tennessee, the U.T. Computing Center, and the Dean of Natural and Social Sciences of the University of Nebraska at Kearney are acknowledged for providing central and/or distributed computing facilities and services. This work was supported in part by the United States Department of Agriculture National Research Initiative Competitive Grants Program (awards 93-37305-9082 and 95-37305-3086 to B. C. M.).

\section{LITERATURE CITED}

Aleith, F., and Richter, G. 1990. Gene expression during induction of somatic embryogenesis in carrot cell suspensions. Planta 183:17-24.

Altschul, S. F., Gish, W., Miller, W., Myers, E. W., and Lipman, D. J. 1990. Basic local alignment search tool. J. Mol. Biol. 215:403-410.

Benson, D. R., and Silvester, W. B. 1993. Biology of Frankia strains, actinomycete symbionts of actinorhizal plants. Microbiol. Rev. 57: 293-319.

Blondel, A., Nageotte, R., and Bedouelle, H. 1996. Destabilizing interactions between the partners of a bifunctional fusion protein. Protein Eng. 9:231-238

Cheon, C. I., Hong, Z., and Verma, D. P. 1994. Nodulin-24 follows a novel pathway for integration into the peribacteroid membrane in soybean root nodules. J. Biol. Chem. 269:6598-602.

Condit, C. M. 1993. Developmental expression and localization of $P e$ tunia glycine-rich protein I. Plant Cell 5:277-288.

Conklin, D. S., McMaster, J. A., Culbertson, M. R., and Kung, C. 1992. COT1, a gene involved in cobalt accumulation in Saccharomyces cerevisiae. Mol. Cell Biol. 12:3678-3788.

Cox, K. H., and Goldberg, R. B. 1988. Analysis of plant gene expression. Pages 1-34 in: Plant Molecular Biology: A Practical Approach. C. H. Shaw, ed. IRL Press, Oxford.

de la Cadena, R. A., and Colman, R. W. 1992. The sequence HGLGHGHEQQHGLGHGH in the light chain of high molecular weight kininogen serves as a primary structural feature for zincdependent binding to an anionic surface. Protein Sci. 1:151-160.

Dellaporta, S. L., Wood, J., and Hicks, J. B. 1983. A plant DNA minipreparation: Version II. Plant Mol. Biol. Rep. 1:19-21.

Denecke, J., De Rycke, R., and Botterman, J. 1992. Plant and mammalian sorting signals for protein retention in the endoplasmic reticulum contain a conserved epitope. EMBO J. 11:2345-2355.

Devereux, J., Haeberli, P., and Smithies, O. 1984. A comprehensive set of sequence analysis programs for the VAX. Nucleic Acids Res. 12: 387-395.

Dixon, R. O. D., and Wheeler, C. T. 1983. Biochemical, physiological and environmental aspects of symbiotic nitrogen fixation. Pages 107171 in: Biological Nitrogen Fixation in Forest Ecosystems: Foundations and Applications. J. C. Gordon and C. T. Wheeler, eds. Nijhoff/ Junk, The Hague, The Netherlands.

Dobritsa, S. V., and Mullin, B. C. 1996. In vitro expression of actinorhizal nodulin AgNOD-GHRP and demonstration of its toxicity to Escherichia coli. Pages 423-428 in: Biology of Plant-Microbe Interactions. G. Stacey, B. Mullin, and P. M. Gresshoff, eds. Int. Soc. Mol. Plant-Microbe Interact., St. Paul, MN.

Domingo, C., Gomez, M. D., Canas, L., Hernandez-Yago, J., Conejero, V., and Vera, P. 1994. A novel extracellular matrix protein from tomato associated with lignified secondary cell walls. Plant Cell 6: 1035-1047.

Ermak, G. Z., Prosnyak, M. I., Vecher, A. A., and Kartel, N. A. 1990. AT repeats in barley genome. FEBS Lett. 272:193-196.

Farber, R. A., Petes, T. D., Dominska, M., Hudgens, S. S., and Liskay, R. M. 1994. Instability of simple sequence repeats in a mammalian cell line. Hum. Mol. Genet. 3:253-256.

Fu, C., Olson, J. W., and Maier, R. J. 1995. HypB protein of Bradyrhizobium japonicum is a metal-binding GTPase capable of binding 18 divalent nickel ions per dimer. Proc. Natl. Acad. Sci. USA 92:23332337.

Gilbert, J. V., Ramakrishna, J., Sunderman, F. W., Jr., Wright, A., and Plaut, A. G. 1995. Protein Hpn: Cloning and characterization of a histidine-rich metal-binding polypeptide in Helicobacter pylori and Helicobacter mustelae. Infect. Immun. 63:2682-2688.

Goetting-Minesky, M. P., and Mullin, B. C. 1994. Differential gene expression in an actinorhizal symbiosis: Evidence for a nodule-specific cysteine proteinase. Proc. Natl. Acad. Sci. USA 91:9891-9895.

Guan, C., Akkermans, A. D. L., van Kammen, A., Bisseling, T., and 
Pawlowski, K. 1997. ag13 is expressed in Alnus glutinosa nodules in infected cells during endosymbiont degradation and in the nodule pericycle. Physiol. Plant. 99:601-607.

Hewitt, E. J., and Bond, G. 1961. Molybdenum and the fixation of nitrogen in Casuarina and Alnus root nodules. Plant Soil 14:159-175.

Hewitt, E. J., and Bond, G. 1966. The cobalt requirement of non-legume root nodule plants. J. Exp. Bot. 52:480-491.

Huss-Danell, K. 1991. Influence of host (Alnus and Myrica) genotype on infectivity, $\mathrm{N}_{2}$ fixation, spore formation, and hydrogenase activity in Frankia. New Phytol. 119:121-127.

Jacobs, F. A., Zhang, M., Fortin, M. G., and Verma, D. P. 1987. Several nodulins of soybean share structural domains but differ in their subcellular locations. Nucleic Acids Res. 15:1271-1280.

Johnson-Schlitz, D. M., and Engels, W. R. 1993. P-element-induced interallelic gene conversion of insertions and deletions in Drosophila melanogaster. Mol. Cell Biol. 13:7006-7018.

Kaldenhoff, R., and Richter, G. 1989. Sequence of cDNA for a novel light-induced glycine-rich protein. Nucleic Acids Res. 17:2853.

Kardailsky, I., Yang, W.-C., Zalensky, A., van Kammen, A., and Bisseling, T. 1993. The pea late nodulin gene PsNOD6 is homologous to the early nodulin genes PsENOD3/14 and is expressed after leghaemoglobin genes. Plant Mol. Biol. 23:1029-1037.

Katinakis, P., and Verma, D. P. S. 1985. Nodulin-24 gene of soybean codes for a peptide of the peribacteroid membrane and was generated by tandem duplication of a sequence resembling an insertion element. Proc. Natl. Acad. Sci. USA 82:4157-4161.

Keil, B. 1992. Specificity of Proteolysis. Springer-Verlag, Berlin.

Kemp, B. E., and Pearson, R. B. 1990. Protein kinase recognition sequence motifs. Trends Biochem. Sci. 15:342-346.

Kouchi, H., and Hata, S. 1993. Isolation and characterization of novel cDNAs representing genes expressed at early stages of soybean nodule development. Mol. Gen. Genet. 238:106-119.

Matsudaira, P. 1987. Sequence from picomole quantities of proteins electroblotted onto polyvinylidene difluoride membranes. J. Biol. Chem. 262:10035-10038.

McLaughlin, S., and Aderem, A. 1995. The myristoyl-electrostatic switch: A modulator of reversible protein-membrane interactions. Trends Biochem. Sci. 20:272-276.

Morgante, M., and Olivieri, A. M. 1993. PCR-amplified microsatellites as markers in plant genetics. Plant J. 3:175-182.

Mylona, P., Pawlowski, K., and Bisseling, T. 1995. Symbiotic nitrogen fixation. Plant Cell 7:869-885.

Nakamura, K., and Matsuoka, K. 1993. Protein targeting to the vacuole in plant cells. Plant Physiol. 101:1-5.

Pawlowski, K. and Bisseling, T. 1996. Rhizobial and actinorhizal symbioses: What are the shared features? Plant Cell 8:1899-1913.

Pawlowski, K., Kunze, R., de Vries, S., and Bisseling, T. 1994. Isolation of total, poly(A) and polysomal RNA from plant tissues. Pages 1-13 in Plant Molecular Biology Manual, D5, 2nd ed. S. B. Gelvin and R. A. Schilperoort, eds. Kluwer Academic Pub., Dordrecht, The Netherlands.

Persing, D. H., Varmus, H. E., and Ganem, D. 1987. The preS1 protein of hepatitis B virus is acylated at its amino terminus with myristic acid. J. Virol. 61:1672-1677.

Ribeiro, A., Akkermans, A. D. L., van Kammen, A., Bisseling, T., and Pawlowski, K. 1995. A nodule-specific gene encoding a subtilisin-like protease is expressed in early stages of actinorhizal nodule development. Plant Cell 7:785-794.

Sambrook, J., Fritsch, E. F., and Maniatis, T. A. 1989. Molecular Cloning: A Laboratory Manual. 2nd ed. Cold Spring Harbor Laboratory, Cold Spring Harbor, NY.

Sánchez, F., Padilla, J. E., Péréz, H., and Lara, M. 1991. Control of nodulin genes in root-nodule development and metabolism. Annu. Rev. Plant Physiol. Plant Mol. Biol. 42:507-528.

Sandal, N. N., Bojsen, K., and Marcker, K. A. 1987. A small family of nodule specific genes from soybean. Nucleic Acids Res. 15:15071519.

Sanger, F., Nicklen, S., and Coulson, A. R. 1977. DNA sequencing with chain-terminating inhibitors. Proc. Natl. Acad. Sci. USA 74:5463-5467.

Scheres, B., Van Engelen, F., Van der Knaap, E., van de Wiel, C., Van Kammen, A., and Bisseling, T. 1990a. Sequential induction of nodulin gene expression in the developing pea nodule. Plant Cell 2:687-700.

Scheres, B., van de Wiel, C., Zalensky, A., Horvath, B., Spaink, H., Van Eck, H., Zwartkruis, F., Wolters, A. M., Gloudemans, T., van Kammen, A., and Bisseling, T. 1990b. The ENOD12 product is involved in the infection process during pea-Rhizobium interaction. Cell 60:281-294.

Smith, J. A. 1988a. Quantitation of proteins. Pages 10.1.1-10.1.3 in: Current Protocols in Molecular Biology, Vol. 2. F. M. Ausubel, R. Brent, R. E. Kingston, D. D. Moore, J. G. Seidman, J. A. Smith, and K. Struhl, eds. Greene Publishing Associates \& Wiley-Interscience, New York.

Smith, J. A. 1988b. Electrophoretic separation of proteins. Pages 10.2.110.2.9 in: Current Protocols in Molecular Biology, Vol. 2. F. M. Ausubel, R. Brent, R. E. Kingston, D. D. Moore, J. G. Seidman, J. A. Smith, and K. Struhl, eds. Greene Publishing Associates \& WileyInterscience, New York.

Twigg, P. G. 1993. Isolation of a nodule-specific cDNA encoding a putative glycine-rich protein from Alnus glutinosa. Ph.D. diss. University of Tennessee, Knoxville.

van de Wiel, C., Scheres, B., Franssen, H., van Lierop, M. J., Van Lammeren, A., Van Kammen, A., and Bisseling, T. 1990. The early nodulin transcript ENOD2 is located in the nodule parenchyma (inner cortex) of pea and soybean root nodules. EMBO J. 9:1-7.

van Kan, J. A., Cornelissen, B. J. C., and Bol, J. F. 1988. A virusinducible tobacco gene encoding a glycine-rich protein shares putative regulatory elements with the ribulose bisphosphate carboxylase small subunit gene. Mol. Plant-Microbe Interact. 1:107-112.

von Heijne, G. 1986. A new method for predicting signal sequence cleavage sites. Nucleic Acids Res. 14:4683-4690.

Wülfing, C., Lombardero, J., and Plückthun, A. 1994. An Escherichia coli protein consisting of a domain homologous to FK506-binding proteins (FKBP) and a new metal binding motif. J. Biol. Chem. 269: 28995-2901. 